\title{
Pengaruh Suhu Perendaman terhadap Pertumbuhan Kecambah Benih Indigofera zollingeriana
}

\author{
(Effect of Soaking Temperature on the Growth of Seed Germination \\ Indigofera zollingeriana)
}

Hutasoit R, Riyadi, Ginting SP

Loka Penelitian Kambing Potong, PO Box 1 Sungai Putih,Galang, Sumatera Utara 20585

h.rijanto@yahoo.com

\begin{abstract}
Development of Indigofera zollingeriana (Indigofera) is still hampered by the lack of seed germination. This study aimed to evaluate the effect of soaking temperature on the growth of seed germination Indigofera, in a completely randomized design, consist of five stage soaking temperature and four replication, namely: $\mathrm{P}_{0}=$ Soaked in normal water temperature $\left(27^{\circ} \mathrm{C}\right), \mathrm{P}_{1}=$ water $40^{\circ} \mathrm{C}, \mathrm{P}_{2}=$ water $60^{\circ} \mathrm{C}, \mathrm{P}_{3}=$ water $80^{\circ} \mathrm{C}$, and $\mathrm{P}_{4}=$ water $100^{\circ} \mathrm{C}$. The results show that the highest germination of $42 \%$ contained in $\mathrm{P} 4\left(100^{\circ} \mathrm{C}\right)$, significantly $(\mathrm{P}<0.05)$ to $\mathrm{P} 3\left(80^{\circ} \mathrm{C}\right)(34 \%)$. The higher sprouts $3,28 \mathrm{~cm}$ and longer root $1,44 \mathrm{~cm}$ contained in the soaking of $100^{\circ} \mathrm{C}$. The simultaneity grew were not significantly different in the treatment of $40,60,80$, and $100^{\circ} \mathrm{C}$. But significant to $27^{\circ} \mathrm{C}(60.37 \%)$. The highest number of sprouts leaves 2.07 sheet contained in the soaking of $100^{\circ} \mathrm{C}$. Indigofera fungal growth on the seed shows that the soaking temperature of $100^{\circ} \mathrm{C}$ can to suppress the fungi. It can be concluded that the soaking temperature of $100^{\circ} \mathrm{C}$ in the process of seeding Indigofera could be recommended for obtaining more advantage.
\end{abstract}

Key Words: Soaking Temperature, Indigofera zollingeriana Seed, Seeding, Sprout

\begin{abstract}
ABSTRAK
Pengembangan tanaman pakan Indigofera zollingeriana (Indigofera) masih terkendala dengan rendahnya daya cambah benih. Penelitian ini bertujuan untuk mengevaluasi efek dari suhu perendaman terhadap pertumbuhan kecambah benih Indigofera, dalam rancangan acak lengkap terdiri atas lima taraf suhu perendaman dan empat ulangan, yaitu: $\mathrm{P}_{0}=$ Direndam dengan air biasa (suhu normal $27^{\circ} \mathrm{C}$ ), $\mathrm{P}_{1}=$ Dengan suhu air $40^{\circ} \mathrm{C}, \mathrm{P}_{2}=$ Dengan suhu air $60^{\circ} \mathrm{C}, \mathrm{P}_{3}=$ Dengan suhu air $80^{\circ} \mathrm{C}$, dan $\mathrm{P}_{4}=$ Dengan suhu air $100^{\circ} \mathrm{C}$. Hasil penelitian menunjukkan bahwa daya tumbuh tertinggi $42 \%$ terdapat pada perlakuan $\mathrm{P} 4\left(100^{\circ} \mathrm{C}\right)$ berbeda nyata $(\mathrm{P}<0,05)$ dengan $\mathrm{P} 3\left(80^{\circ} \mathrm{C}\right)$ sebesar 34\%. Pengukuran kecambah tertinggi $3,28 \mathrm{~cm}$ dan akar terpanjang $1,44 \mathrm{~cm}$ terdapat pada suhu perendaman $100^{\circ} \mathrm{C}$. Keserempakan tumbuh tidak berbeda nyata pada perlakuan suhu 40,60 , 80 , dan $100^{\circ} \mathrm{C}$. Namun nyata terhadap suhu $27^{\circ} \mathrm{C}$ sebesar $(60,37 \%)$. Jumlah daun kecambah terbanyak 2,07 helai terdapat pada suhu pemanasan $100^{\circ} \mathrm{C}$. Pertumbuhan jamur pada benih Indigofera menunjukkan bahwa semakin tinggi suhu perendaman semakin sedikit terdapat jamur, dengan suhu perendaman $100^{\circ} \mathrm{C}$ dapat menekan tumbuhnya jamur. Disimpulkan bahwa suhu perendaman $100^{\circ} \mathrm{C}$ dalam peroses penyemaian benih Indigofera dapat direkomendasikan karena memperoleh lebih banyak keuntungan.
\end{abstract}

Kata Kunci: Suhu Perendaman, Benih Indigofera zollingeriana, Penyemaian, Kecambah

\section{PENDAHULUAN}

Tanaman leguminosa merupakan hijauan pakan ternak yang sangat dibutuhkan sebagai sumber protein nabati, salah satunya adalah Indigofera zollingeriana (Indigofera). Tanaman leguminosa ini memiliki potensi sebagai hijauan pakan sumber protein dan mineral yang tinggi, struktur serat yang baik dan nilai kecernaan yang tinggi dapat 
meningkatkan produktivitas ternak ruminansia. Tanaman ini juga toleran terhadap musim kering, genangan air dan tahan terhadap salinitas (Hassen et al. 2008; Smykal et al. 2014; Suharlina et al. 2016).

Keberadaan Indigofera di Indonesia sudah cukup berkembang dan banyak dimanfaatkan khususnya pada ternak ruminansia, baik secara langsung diberikan dalam bentuk segar maupun diolah menjadi tepung sebagai bahan pakan atau pakan komplit. Loka Penelitian Kambing Potong adalah salah satu UPT yang sudah banyak mengembangkan dan memanfaatkan Indigofera sebagai pakan ternak kambing. Secara agronomis tanaman Indigofera dikembangkan melalui benih, di samping sebagai pakan ternak, tanaman ini juga telah dijadikan pohon indukan sebagai sumber benih. Ketersediaan benih merupakan salah satu hal yang sangat penting dalam memenuhi ketersediaan Indigofera. Permintaan benih Indigofera setiap tahunnya selalu meningkat dari berbagai daerah di Indonesia, namun demikian untuk mengecambahkan benih Indigofera masih mengalami kendala, karena benih Indigofera memiliki masa dormansi. Beberapa stakeholder melaporkan bahwa tingkat pertumbuhan kecambah benih Indigofera yang dihasilkan terlalu rendah, sehingga mengakibatkan perkembangan tanaman terhambat. Diduga dormansi pada benih Indigofera merupakan dormansi fisik. Menurut Schmidt (2002), dormansi fisik disebabkan oleh kulit buah yang keras dan impermeable atau penutup buah yang menghalangi air yang masuk kedalam benih (imbibisi) dan pertukaran gas. Oleh karena itu, diperlukan skarifikasi yang tepat terhadap benih untuk mematahkan dormansinya dan salah satu teknik yang paling mudah adalah dengan cara perendaman. Perendaman dengan suhu yang berbeda-beda diharapkan akan dapat meningkatkan daya kecambah dan persentase perkecambahan biji Indigofera. Semakin tinggi suhu perendaman yang digunakan sampai batas tertentu akan semakin meningkatkan viabilitas benih (Lubis et al. 2014). Perlakuan melunakkan kulit benih melalui perendaman dapat mempermudah masuknya air ke dalam benih sehingga embrio dapat segera tumbuh tanpa hambatan (Hardianti et al. 2014).

Informasi rinci pengaruh suhu terhadap perkecambahan benih Indigofera sangat penting untuk mengembangkan spesies ini, perkecambahan biji adalah salah satu langkah kunci dalam siklus kehidupan tanaman. Hal ini sangat menentukan awal pertumbuhan tanaman di ekosistem alam atau pertanian. Karakteristik benih Indigofera memiliki kulit yang keras menjadi penghalang mekanis terhadap masuknya air dan gas sehingga sulit untuk berkecambah. Dengan demikian upaya yang perlu dilakukan untuk mengatasi hal tersebut adalah dengan cara menguji daya kecambah benih pada saat penyemaian. Daya berkecambah atau daya tumbuh benih adalah tolok ukur bagi kemampuan benih untuk tumbuh normal dan berproduksi normal pada kondisi lingkungan yang optimum (Bewley et al. 2013). Penelitian ini bertujuan untuk mengevaluasi efek dari suhu perendaman terhadap pertumbuhan kecambah benih I. zollingeriana.

\section{MATERI DAN METODE}

Kegiatan ini dilaksanakan di Laboratorium Loka Penelitian Kambing Potong Sei Putih, Kabupaten Deliserdang, Sumatera Utara, terletak pada ketinggian $\pm 50 \mathrm{~m}$ dari permukaan laut dengan rata-rata suhu $27^{\circ} \mathrm{C}$, kelembaban $70 \%$ dan curah hujan sebanyak $1800 \mathrm{~mm} /$ tahun. Waktu penelitian dilaksanakan pada bulan Januari sampai dengan Pebruari 2017. Benih tanaman leguminosa yang digunakan yaitu: I. zollingeriana, sebanyak 15 g. Penelitian ini dilaksanakan dengan menggunakan Rancangan Acak Lengkap (RAL) yang terdiri atas lima taraf perendaman, yaitu : $\mathrm{P} 0=$ Direndam dengan air biasa (suhu air normal $27^{\circ} \mathrm{C}$ ), $\mathrm{P} 1=$ Direndam dengan suhu air $40^{\circ} \mathrm{C}, \mathrm{P} 2=$ Direndam dengan suhu air $60^{\circ} \mathrm{C}, \mathrm{P} 3=$ Direndam dengan suhu air $80^{\circ} \mathrm{C}$, dan $\mathrm{P} 4=$ Direndam dengan 
suhu air $100^{\circ} \mathrm{C}$. Masing-masing perlakuan dengan 4 ulangan sehingga terdapat 20 cawan perlakuan. Benih Indigofera direndam didalam cawan petri sesuai dengan perlakuan suhu selama 1 malam (12 jam), selanjutnya air ditiriskan dan disemai ke dalam cawan petri yang dasarnya sudah dilapisi dengan kapas yang basah (lembab). Masing-masing cawan disemai sebanyak 100 benih Indigofera sehingga total benih yang dibutuhkan sebanyak 2000 benih. Benih diamati mulai hari ke-2 sampai hari ke-12 setelah penyemaian. Parameter yang diamati adalah:

a. Daya cambah benih (Dcb), yaitu persentase jumlah benih yang berkecambah sampai akhir pengujian.

$$
\text { Dcb }=\frac{\Sigma \text { Benih yang berkecambah }}{\Sigma \text { Total benih yang ditanam }} \times 100 \%
$$

b. Pengukuran kecambah benih Indigofera, dengan mengukur tinggi kecambah dan panjang akar primer. Pengukuran dilakukan pada hari ke-12 terakhir pengamatan dengan menggunakan alat ukur. Tinggi kecambah diukur mulai pangkal kecambah sampai dengan ujung kecambah. Sedangkan panjang akar primer diukur mulai pangkal kecambah sampai ujung akar primer.

c. Pertumbuhan kecambah benih Indigofera, yang diamati adalah rata-rata hari berkecambah, keserempakan tumbuh dan jumlah daun kecambah. Rata-rata hari berkecambah diamati mulainya benih berkecambah sampai tidak ada lagi benih yang berkecambah. Sedangkan keserempakan tumbuh (Kst) benih dihitung menggunakan rumus sebagai berikut:

$$
\mathrm{Kst}=\frac{\begin{array}{c}
\Sigma \text { Benih yang serempak } \\
\text { berkecambah }
\end{array}}{\Sigma \text { Total benih yang ditanam }} \times 100 \%
$$

Untuk memperoleh jumlah daun kecambah (Jdk) dihitung dengan rumus:

$$
\mathrm{Jdk}=\frac{\Sigma \text { Daun yang tumbuh }}{\Sigma \text { Kecambah yang tumbuh }}
$$

d. Pertumbuhan jamur benih Indigofera (Pjb). Dalam pengamatan terhadap kesehatan perkecambahan benih dilakukan secara makroskopis. Gejala yang muncul adalah berupa jamur yang ditandai dengan adanya benang-benang hifa berwarna putih dan bintik-bintik hitam (Meilan et al. 2014). Munculnya koloni jamur pada saat perkecambahan benih dihitung dengan rumus sebagai berikut:

$$
\mathrm{Pjb}=\frac{\Sigma \text { Kecambah berjamur }}{\Sigma \text { Benih yang ditanam }} \times 100 \%
$$

Seluruh data yang diperoleh dianalisis varian, perbedaan antara perlakuan diuji dengan uji DMRT.

\section{HASIL DAN PEMBAHASAN}

\section{Pengaruh suhu perendaman terhadap daya cambah benih Indigofera}

Hasil pengamatan terhadap daya cambah benih Indigofera (Gambar 1) menunjukkan bahwa persentase daya cambah pada perlakuan perendaman memperoleh hasil yang berbeda nyata $(\mathrm{P}<0,05)$. Perlakukan $\mathrm{P} 3$ menghasilkan daya cambah lebih rendah $(34 \%)$. Tingginya persentase daya tumbuh pada perlakuan P4 (suhu perendaman $100^{\circ} \mathrm{C}$ ) kemungkinan besar disebabkan karena panasnya air dapat melunakkan lapisan luar benih Indigofera yang sangat keras sehingga embrio benih dengan mudah menembus lapisan benih dan keluar menjadi kecambah. 


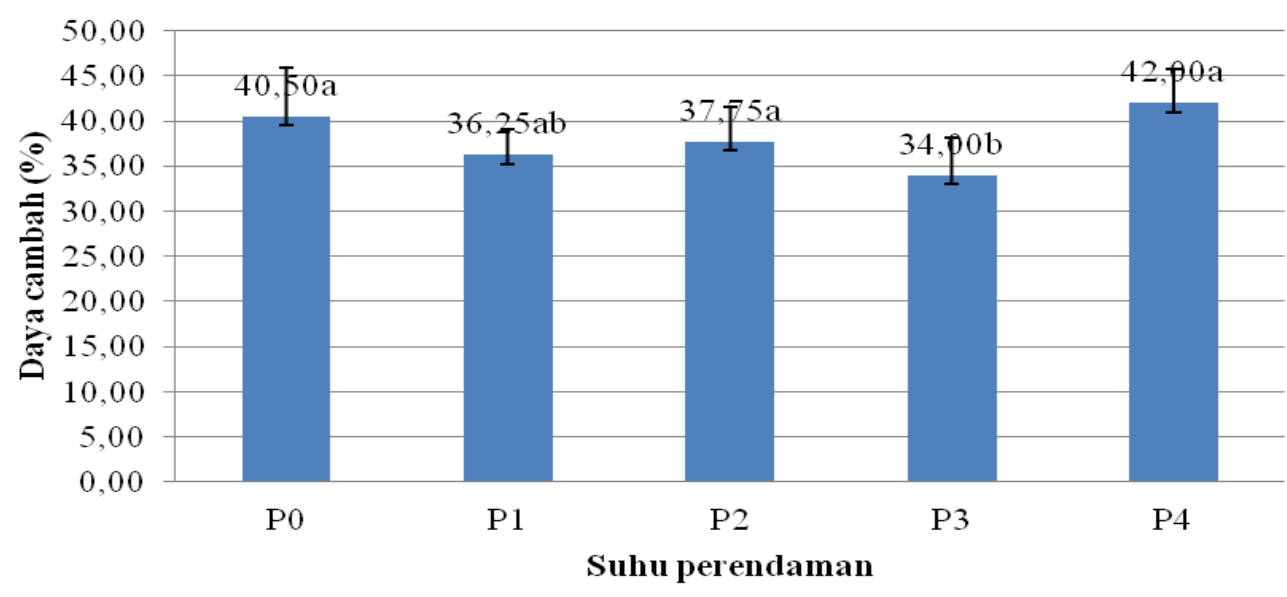

P0: Direndam dengan air biasa (suhu normal $27^{\circ} \mathrm{C}$ ); P1: Dengan suhu air $40^{\circ} \mathrm{C} ; \mathrm{P} 2$ : Dengan suhu air $60^{\circ} \mathrm{C}$; P3: Dengan suhu air $80^{\circ}$; P4: Dengan suhu air $100^{\circ} \mathrm{C}$

Gambar 1. Daya cambah benih pada beberapa suhu perendaman

Persentase daya cambah benih Indigofera pada penelitian ini tergolong rendah. Menurut Ditjen Tanaman Pangan (1991) Standar benih sesuai dengan SNI minimal memiliki daya tumbuh 75\%. Hal ini diperkuat oleh pendapat Kartasapoetra (2003), menyatakan bahwa benih yang berkualitas tinggi itu memiliki viabilitas lebih dari 90 persen sehingga tanaman mampu tumbuh secara normal pada kondisi yang sub optimum dan dapat berproduksi secara maksimal. Rendahnya kualitas benih Indigofera mungkin disebabkan karena benih yang digunakan dalam penelitian ini adalah benih yang baru dipanen, belum mengalami masa dormansi sehingga embrio pada benih belum masak dan belum siap tumbuh. Kurangnya teknologi pascapanen seperti teknik pemipilan, penjemuran dan seleksi benih yang dilakukan kemungkinan juga faktor penyebab rendahnya kualitas benih yang diperoleh. Dibanding dengan penelitian lainnya hasil penelitian ini lebih tinggi dari daya cambah yang dilaporkan oleh Girsang (2012) yang menggunakan $\mathrm{CO} 2$ sebagai bahan yang diinjeksikan pada benih Indigofera dengan daya cambah $18 \%$ jauh dibawah nilai SNI. Abdullah (2014) melaporkan bahwa perlakuan benih skarafikasi dengan suhu pemanasan kering $30^{\circ} \mathrm{C}$ memperoleh daya cambah $59 \%$ dan pada suhu $45^{\circ} \mathrm{C}$ menjadi $29 \%$. Lebih lanjut dijelaskan bahwa rendahnya daya cambah tersebut umumnya disebabkan oleh kulit benih yang tebal dan invasi jamur pada saat perkecambahan, namun setelah diberi bahan organik pada media penyemaian daya kecambah meningkat menjadi 67-74\%.

\section{Pengukuran kecambah benih Indigofera}

Tinggi tanaman merupakan salah satu indikator mengukur pertumbuhan (Risva et al. 2014). Semakin tinggi kecambah/tunas pada tanaman mengindikasikan semakin tinggi pertumbuhan dan berpengaruh terhadap produksi tanaman, sehingga dapat mempercepat umur pemotongan (panen). Tingginya pertumbuhan kecambah benih Indigofera dalam penelitian ini dipengaruhi oleh suhu perendaman yang mengakibatkan dimensi (panjang, tinggi, dan lebar) menjadi lebih besar dan akhirnya mencapai dimensi maksimum. Perubahan dimensi tersebut diakibatkan karena suhu yang panas dapat merusak kristalinitas amilosa dan helix sehingga granula membengkak menyebabkan proses reaksi yang lebih cepat masuknya air ke dalam benih (Nani et al. 2013). Dari hasil analisis variansi menunjukkan bahwa perlakuan suhu perendaman $\mathrm{P} 4\left(100^{\circ} \mathrm{C}\right), \mathrm{P} 0\left(27^{\circ} \mathrm{C}\right), \mathrm{P} 1$ 
$\left(40^{\circ} \mathrm{C}\right)$ dan $\mathrm{P} 3\left(80^{\circ} \mathrm{C}\right)$ tidak berbeda nyata terhadap pertumbuhan tinggi kecambah, sementara perlakuan $\mathrm{P} 2\left(60^{\circ} \mathrm{C}\right)$ lebih rendah hasilnya dan berbeda nyata $(\mathrm{P}<0,05)$.

Tabel 1. Tinggi kecambah dan panjang akar primer benih Indigofera

\begin{tabular}{lccccc}
\hline \multirow{2}{*}{ Parameter } & \multicolumn{5}{c}{ Suhu perendaman } \\
\cline { 2 - 6 } & $\mathrm{P} 0$ & $\mathrm{P} 1$ & $\mathrm{P} 2$ & $\mathrm{P} 3$ & $\mathrm{P} 4$ \\
\hline Tinggi kecambah $(\mathrm{cm})$ & $2,87 \pm 0,32^{\mathrm{a}}$ & $2,6 \pm 0,45^{\mathrm{a}}$ & $2,15 \pm 0,19^{\mathrm{b}}$ & $2,65 \pm 0,43^{\mathrm{a}}$ & $3,28 \pm 0,54^{\mathrm{a}}$ \\
Panjang akar primer $(\mathrm{cm})$ & $0,96 \pm 0,10^{\mathrm{c}}$ & $1,02 \pm 0,13^{\mathrm{c}}$ & $1,15 \pm 0,19^{\mathrm{b}}$ & $1,14 \pm 0,16^{\mathrm{b}}$ & $1,44 \pm 0,27^{\mathrm{a}}$ \\
\hline
\end{tabular}

P0: Direndam dengan air biasa (suhu normal $27^{\circ} \mathrm{C}$ ); P1: Dengan suhu air $40^{\circ} \mathrm{C}$; P2: Dengan suhu air $60^{\circ} \mathrm{C}$; P3: Dengan suhu air $80^{\circ} \mathrm{C}$; P4: Dengan suhu air $100^{\circ} \mathrm{C}$; Angka yang diikuti superskrip yang berbeda pada baris yang sama menunjukkan perbedaan yang nyata $(\mathrm{P}<0,05)$

Hasil penelitian terhadap panjang akar primer menunjukkan semakin tinggi suhu perendaman semakin tinggi panjang akar yang diperoleh (Tabel 1). Akar kecambah terpanjang $(1,44 \mathrm{~cm})$ diperoleh pada perlakuan perendaman suhu tertinggi $\left(100^{\circ} \mathrm{C}\right)$ berbeda nyata $(\mathrm{P}<0,05)$ terhadap ke empat suhu perendaman lainnya. Panjang akar dapat memacu pertumbuhan awal tanaman dan meningkatkan kemampuan untuk menyerap air beserta unsur-unsur hara yang terlarut di dalamnya (Hidayanto et al. 2003; Nio \& Patricia 2013) dengan terbentuknya akar lebih awal maka pertumbuhan tanaman menjadi lebih baik. Panjang pendeknya akar kecambah ini kemungkinan besar disebabkan karena faktor keras lunaknya kulit/lapisan luar benih. Diketahui kulit benih Indigofera tergolong keras berwarna cokelat kehitaman sehingga perlu skarafikasi sebelum dilakukan penyemaian. Dengan skarafikasi perendaman suhu yang tinggi mengakibatkan lapisan kulit benih semakin lunak, melalui proses difusi penyerapan air meningkat sehingga dengan mudah ditembus oleh akar dan cepat berkembang dalam media perkecambahan.

\section{Pertumbuhan kecambah benih Indigofera}

Pertumbuhan benih Indigofera dapat dilihat pada Tabel 2. Benih berkecambah mulai hari ke-2 yang diawali dengan terbelahnya benih dan keluarnya akar, mulai membentuk batang dan daun pada hari keempat. Waktu yang dibutuhkan untuk pertumbuhan kecambah benih dipengaruhi lama perendaman. Semakin lama benih berkecambah mengindikasikan bahwa vigor benih semakin berkurang sehingga kecambah yang diperoleh pendek, ukuran daun kecil, hipokotil pendek dan volume akar kecil.

Keserempakan perkecambahan benih adalah kemampuan suatu lot benih untuk berkecambah serempak, uji keserempakan perkecambahan merupakan salah satu uji vigor kekuatan perkecambahan benih, memberikan gambaran berapa persen benih-benih yang mampu berkecambah normal. Menurut Sadjad (1993) keserempakan tumbuh benih yang <40 persen mengindikasikan benih kurang vigor. Hasil penelitian ini menunjukkan keserempakan tumbuh kecambah tergolong tinggi dan normal (kisaran 60,37-89,42\%), tidak berbeda nyata antara suhu perendaman, namun berbeda nyata $(\mathrm{P}<0,05)$ terhadap perendaman dengan suhu normal (P0). Ardian (2008) melaporkan benih bervigor kuat ditunjukkan oleh keserempakan perkecambahan yang tinggi serta pembentukan pertanaman akar dan daun secara homogen dan seragam, benih yang tumbuh cepat dan serempak lebih mampu menghadapi kondisi lapang yang suboptimum. 
Tabel 2. Pertumbuhan kecambah benih Indigofera

\begin{tabular}{lccccc}
\hline \hline \multirow{2}{*}{ Parameter } & \multicolumn{5}{c}{ Suhu perendaman } \\
\cline { 2 - 6 } & $\mathrm{P}_{0}$ & $\mathrm{P}_{1}$ & $\mathrm{P}_{2}$ & $\mathrm{P}_{3}$ & $\mathrm{P}_{4}$ \\
\hline $\begin{array}{l}\text { Rata-rata hari } \\
\text { berkecambah }\end{array}$ & $5,5 \pm 2,38^{\mathrm{a}}$ & $7,75 \pm 2,87^{\mathrm{ab}}$ & $4,25 \pm 1,89^{\mathrm{a}}$ & $8,0 \pm 2,94^{\mathrm{b}}$ & $6,75 \pm 1,7^{\mathrm{a}}$ \\
$\begin{array}{l}\text { Keserempakan } \\
\text { tumbuh (\%) }\end{array}$ & $60,37 \pm 11,14^{\mathrm{b}}$ & $84,52 \pm 7,10^{\mathrm{a}}$ & $87,47 \pm 5,68^{\mathrm{a}}$ & $89,42 \pm 2,80^{\mathrm{a}}$ & $88,68 \pm 8,69^{\mathrm{a}}$ \\
$\begin{array}{l}\text { Jumlah daun } \\
\text { kecambah (helai) }\end{array}$ & $0,84 \pm 1,0^{\mathrm{b}}$ & $1,41 \pm 1,8^{\mathrm{ab}}$ & $1,00 \pm 0,81^{\mathrm{b}}$ & $1,60 \pm 1,3^{\mathrm{a}}$ & $2,07 \pm 2,01^{\mathrm{a}}$ \\
\hline
\end{tabular}

P0: Direndam dengan air biasa (suhu normal $27^{\circ} \mathrm{C}$ ); P1: Dengan suhu air $40^{\circ} \mathrm{C}$; P2: Dengan suhu air $60^{\circ} \mathrm{C}$; P3: Dengan suhu air $80^{\circ} \mathrm{C}$; P4: Dengan suhu air $100^{\circ} \mathrm{C}$; Angka yang diikuti superskrip yang berbeda pada baris yang sama menunjukkan perbedaan yang nyata $(\mathrm{P}<0,05)$

Kekuatan tumbuh yang tinggi tersebut mempengaruhi kecepatan proses pembentukan daun. Analisis statistik menunjukkan bahwa perendaman benih pada suhu tinggi nyata terhadap jumlah daun yang diperoleh. Hal ini berkaitan erat dengan meningkatkan zat tumbuh gibberallin yang diperoleh akibat suhu perendaman yang tinggi. Weiss \& Ori (2007) melaporkan bahwa salah satu efek fisiologis dari giberelin adalah mendorong aktivitas enzim-enzim hidrolitik pada proses perkecambahan benih.

\section{Pertumbuhan jamur pada benih Indigofera}

Benih Indigofera yang digunakan dalam penelitian ini cenderung berjamur ketika dikecambahkan. Menurut Budiarti et al. (2013) tumbuhnya jamur pada benih dapat mengakibatkan penurunan daya kecambah, perubahan warna, kenaikan suhu dan kelembaban di dalam benih, perubahan susunan kimia di dalam benih dan produksi dan akumulasi mikotoksin di dalam benih.

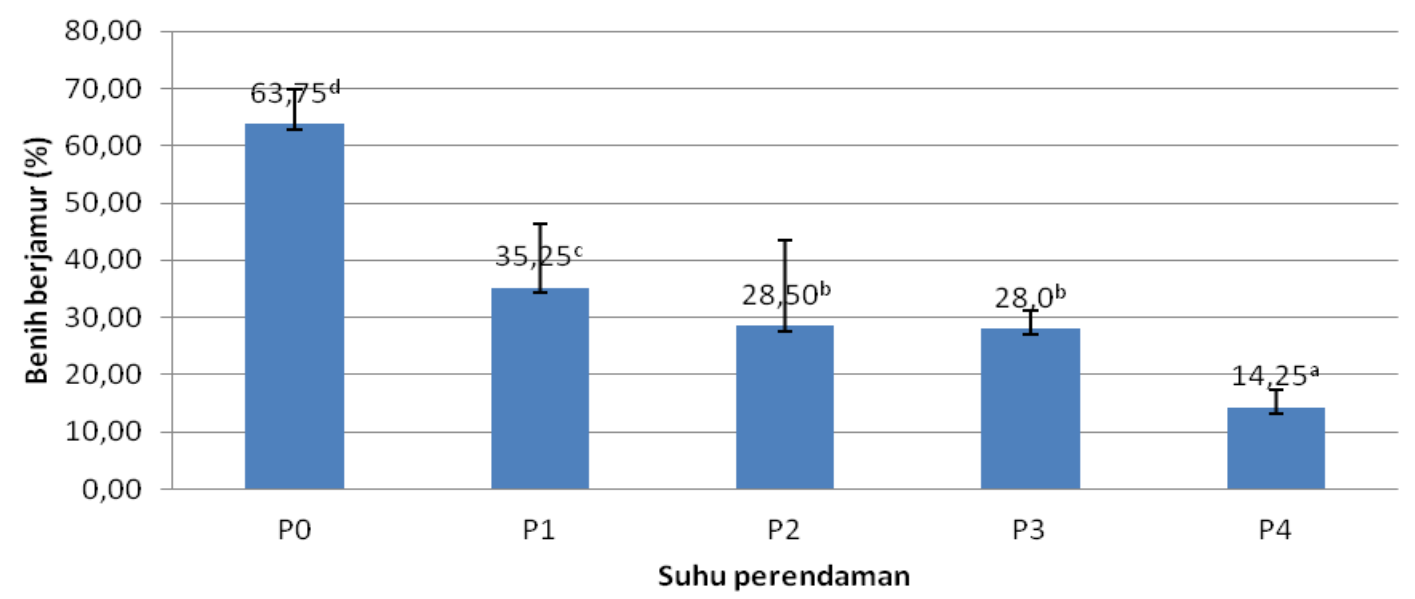

P0: Direndam dengan air biasa (suhu normal $27^{\circ} \mathrm{C}$ ); P1: Dengan suhu air $40^{\circ} \mathrm{C}$; P2: Dengan suhu air $60^{\circ} \mathrm{C}$; P3: Dengan suhu air $80^{\circ}$; P4: Dengan suhu air $100^{\circ} \mathrm{C}$

Gambar 2. Pertumbuhan jamur pada benih Indigofera

Pada Gambar 2 terlihat bahwa semakin tinggi suhu perendaman semakin sedikit terdapat jamur. Jumlah benih berjamur paling sedikit terdapat pada perlakuan suhu tertinggi $100^{\circ} \mathrm{C}(\mathrm{P} 4)$ sebanyak $14,25 \%$, berbeda nyata $(\mathrm{P}<0,05)$ terhadap ke empat perlakuan suhu lainnya yaitu berturut-turut sebesar 28,0\% (P3), 28,5\% (P2), 35,32\% (P1) 
dan 63,75\% (P0). Hal ini kemungkinan besar disebabkan karena panasnya air perendaman dapat menghambat pertumbuhan jamur pada benih Indigofera. Munculnya jamur pada benih kemungkinan besar disebabkan kelembaban tinggi pada tiap perlakuan perendaman (Sudir et al. 2014) yang dapat menginduksi munculnya jamur, patogen yang berasal dari udara mengkontaminasi benih Indigofera juga menjadi alasan munculnya koloni jamur pada saat perkecambahan benih, ada juga kemungkinan bahwa jamur yang tumbuh adalah jamur yang berasal dari dalam benih (seed borne), hal ini selaras dengan yang dilaporkan Abdullah (2014) bahwa tanaman indukan sudah diserang cendawan sehingga secara sistemik diduga sudah menginfeksi semua benih yang ada. Dengan demikian suhu perendaman $100^{\circ} \mathrm{C}$ dapat direkomendasikan pada benih Indigofera karena mampu menghilangkan lebih banyak jamur pada saat penyemaian.

\section{KESIMPULAN}

Dari hasil penelitian ini dapat disimpulkan bahwa suhu perendaman berpengaruh terhadap pertumbuhan kecambah benih Indigofera. Suhu perendaman $100^{\circ} \mathrm{C}$ menghasilkan persentase daya cambah dan keserampakan perkecambahan yang tinggi, jumlah daun dan ukuran kecambah cukup tinggi dan akar yang panjang. Tingginya suhu perendaman juga menghasilkan akar primer terpanjang dan dapat menghambat pertumbuhan jamur. Dengan demikian, perendaman benih pada suhu $100^{\circ} \mathrm{C}$ dalam proses penyemaian benih Indigofera dapat direkomendasikan karena memperoleh lebih banyak keuntungan.

\section{DAFTAR PUSTAKA}

Abdullah L. 2014. Prospektif agronomi dan ekofisiologi Indigofera zollingeriana sebagai tanaman penghasil hijauan pakan berkualitas tinggi. Pastura. 3:79-83.

Ardian. 2008. Pengaruh perlakuan suhu dan waktu pemanasan benih terhadap perkecambahan kopi Arabika (coffee arabica). [Internet]. [5 Maret 2017]. Available at: http://bdpunib.org/akta/ artikelakta/2008/25.pdf.

Budiarti SW, Heni P, Suwarti. 2013. Kontaminasi fungi Aspergillus sp pada biji jagung di tempat penyimpanan dengan kadar air yang berbeda. Dalam: Prosiding Seminar Nasional Serealia. Yogyakarta (Indonesia): Balai Pengkajian Teknologi Pertanian. hlm. 482-487.

Bewley JD, Bradford KJ, Hilhorst HWM, Nonogaki H. 2013. Seeds: Physiology of development, germination and dormancy. 3rd Ed. New York (USA): Springer. p. 133-181.

Ditjen Tanaman Pangan. 1991. Petunjuk pengawas benih. Jakarta (Indonesia): Direktorat Bina Produksi Padi dan Palawija Sub Direktorat pengawasan Mutu dan Sertifikasi Benih.

Girsang RC. 2012. Viabilitas benih Indigofera (Indigofera zollingeriana) setelah injeksi karbon dioksida $\left(\mathrm{CO}_{2}\right)$ dan penyimpanan [Skripsi]. [Bogor (Indonesia)]: Institut Pertanian Bogor.

Hardianti PS, Hanum C, Charloq. 2014. Daya kecambah dan pertumbuhan Mucuna bracteata melalui pematahan dormansi dan pemberian zat pengatur tumbuh giberelin (ga3). J Agroekoteknol. 2:630-644.

Hassen A, Rethman NFG, Apostolides Z, Niekerk WA. 2008. Forage production and potential nutritive value of 24 shrubby Indigofera accessions under field conditions in South Africa. Tropical Grasslands. 42:96-103.

Hidayanto M, Siti N, Yossita F. 2003. Pengaruh panjang stek akar dan konsentrasi natriumnitrofenol terhadap pertumbuhan stek akar sukun. J Pengkajian Pengembangan Teknologi Pertanian. 6:154-160.

Kartasapoetra AG. 2003. Teknologi benih - Pengolahan benih. Jakarta (Indonesia): Rineka Cipta. 
Lubis YA, Melya R, Afif B. 2014. Pengaruh lama waktu perendaman dengan air terhadap daya berkecambah trembesi (Samanea saman). J Sylva Lest. 2:25-32.

Meilan S, Azis P, Sulandari S. 2014. Pengaruh pemanasan terhadap perkecambahan dan kesehatan benih kedelai (Glycine max (L) Merrill). Vegetalika. 3:27-37.

Nanik A, Waluyo S, Warji, Tamrin. 2013. Pengaruh suhu perendaman terhadap koefisien difusi dan sifat fisik kacang merah (Phaseolus vulgaris 1). J Tekonologi Pertanian Lampung. 2:3542.

Nio SA, Patricia T. 2013. Karakter morfologi akar sebagai indikator kekurangan air pada tanaman. J Bioslogos. 3:32-39.

Putra SN. 2008. Optimalisasi formula dan proses pembuatan mie jagung dengan metode kalendering [Skripsi]. [Bogor (Indonesia)]: Institut Pertanian Bogor.

Risva AH, Tohari, Sri NHU. 2014. Takaran pupuk nitrogen dan silika terhadap pertumbuhan awal (Saccharum officinarum L) pada inceptisol. Vegetalika. 3:35-44.

Sadjad S. 1993. Dari benih kepada benih. Jakarta (Indonesia): Gramedia.

Schmidt L. 2002. Pedoman penanganan benih tanaman hutan tropis dan subtropis. Jakarta (Indonesia): Direktorat Jenderal Rehabilitasi Lahan dan Perhutanan, Departemen Kehutanan.

Smýkal P, Vernoud V, Blair MW, Soukup A, Thompson RD. 2014. The role of the testa during development and in establishment of dormancy of the legume seed. Front Plant Sci. 5:351.

Sudir, Nasution A, Santoso, Nuryanto B. 2014. Penyakit blas Pyricularia grisea pada tanaman padi dan strategi pengendaliannya. IPTEK Tanam Pangan. 9:85-96.

Suharlina, Dewi A, Nahrowi, Jayanegara A, Abdullah L. 2016. Nutritional evaluation of dairy goat rations containing Indigofera zollingeriana by using in vitro rumen fermentation technique (RUSITEC). Int J Dairy Sci. 11:100-105.

Weiss D, Ori N. 2007. Mechanisms of cross talk beetween gibberellin and other hormones. Plant Physiol. 144:1240-1246.

\section{DISKUSI}

\section{Pertanyaan}

Apakah pada saat perendaman dengan suhu panas akan memecahkan benih, apakah tujuannya juga untuk mensterilkan benih?

\section{Jawaban}

Suhu perendaman tidak memecahkan benih, namun melunakkan sehingga embrio akan mudah menembus kulit benih. Dengan air panas tersebut otomatis mengurangi pertumbuhan jamur pada benih. 